\title{
Kan suicidal atferd ha syklisk karakter? En kasusbeskrivelse
}

\author{
Ved Alexandra Naletova
}

\section{Denne artikkelen gir en beskrivelse av det sykliske mønsteret i suicidalitet hos en pasient som lider av PMDD (Premenstrual Dysphoric Disorder). Mulige biologiske forklaringer for observerte fenomener blir drøftet.}

\section{Innledning}

Kjønnsforskjeller i forekomst av psykiske lidelser hos kvinner og menn er et velkjent fenomen. Psykiske forstyrrelser, spesielt affektive og angstlidelser, som oppstår i menarke, premenstruelt, postpartum og i perimenopause, har stor klinisk betydning. Et nytt begrep, "kvinners reproduktivt relaterte lidelser", har vært omdiskutert i det siste (Halbreich, 2010). En gjennomgang av studier gjort de siste 40 år av sammenhengen mellom ulike faser i menstruasjonssyklus og suicidal atferd - gjort i en litteraturoversikt av Baca-Garcia med kolleger (Baca-Garcia et al., 2000) - viser at funnene spriker: I en rekke studier har man ikke funnet noen assosiasjon, mens i andre ble det påvist $\varnothing \mathrm{kt}$ forekomst av suicidalfors $\varnothing \mathrm{k}$ i sen luteal fase (premenstruell uke) eller $\varnothing \mathrm{kt}$ forekomst avsuicidalfors $\varnothing \mathrm{k}$ og gjennomf $\varnothing$ rt suicid i tidlig follikulær fase (menstruasjonsuke). I noen få studier er det påvist $\varnothing \mathrm{kt}$ forekomst av suicidalfors $\varnothing \mathrm{k}$ i perimenstruell periode (både i sen luteal og tidlig follikulær fase) (Baca-Garcia et al., 2000). En nyere studie viser $\phi \mathrm{kt}$ risiko for suicidal atferd hos kvinner når фstrogen- og progesteronnivåer er lave (menstruell fase av menstruasjonssyklus, menopause og amenore) (Baca-Garcia et al., 2010). Saunders og Hawton har, etter systematisk gjennomgang av relevante studier, funnet at man oftere observerer ikke-dødelig suicidal atferd i faser av menstruasjonssyklus med lavt фstrogennivå og hos kvinner med premenstruelle plager (Saunders \& Hawton, 2006). Premenstruelle plager oppstår i luteal fase av menstruasjonssyklusen og forsvinner med begynnelsen av menstruasjon. De inkluderer emosjonelle, fysiske, kognitive og atferdsmessige forstyrrelser (Halbreich et al., 2007). Man tror at så mange som 70-90 \% av kvinner i fertil alder i st $\varnothing$ rre eller mindre grad opplever plager relatert til menstruasjonssyklus (Braverman, 2007). Flere epidemiologiske studier har påvist at mellom 3 og $8 \%$ av fertile kvinner har så alvorlige premenstruelle plager at en PMDD-diagnose kan bli stilt (Halbreich et al., 2003). Noen få studier har unders $\varnothing \mathrm{kt}$ risiko for suicidal atferd hos kvinner med PMS (Premenstruelt syndrom) (ICD-10 diagnosekode N94.3) og PMDD. Baca-Garcia et al. har ikke funnet $\varnothing \mathrm{kt}$ forekomst av suicidal atferd i premenstruell uke hos kvinner med PMDD sammenlignet med kvinner uten PMDD (Baca-Garcia et al., 2004), mens Wittchen et al. har påvist $\varnothing \mathrm{kt}$ risiko for suicidalfors $\varnothing \mathrm{k}$ og moderat $\varnothing \mathrm{kt}$ risiko for suicidaltanker hos kvinner med PMDD (Wittchen et al., 2002). En subgruppe av ungdommer unders $\varnothing \mathrm{kt}$ for prevalens og alvorlighetsgrad av premenstruelle symptomer, rapporterte suicidaltanker som en del av deres premenstruelle plager (Cleckner-Smith et al., 1998). I en studie hvor 68 kvinner med premenstruelle plager var unders $\varnothing \mathrm{kt}$ for somatiske og psykiske problemer, fant man at $75 \%$ hadde suicidaltanker og $21 \%$ hadde tidligere suicidalfors $\varnothing \mathrm{k}$. Til forskjell var det tilsvarende blant kvinner i kontrollgruppen fra generell gynekologisk praksis bare $17 \%$ som rapporterte om suicidaltanker og 3\% som rapportert om tidligere suicidalfors $\varnothing \mathrm{k}$. De fleste av kvinnene (tre av fire) med flere tidligere suicidalfors $\varnothing \mathrm{k}$ opplyste at de hadde pr $\varnothing v d$ å ta livet av seg enten i løpet av siste uke før eller f $\varnothing$ rste to dager etter menstruasjonens start (Keye et al., 1986).

I den følgede kasusbeskrivelsen gis et interessant eksempel på hvordan repeterende suicidalatferd kan være en del av det kliniske bildet ved PMDD - en lidelse man kanskje ikke vier så mye oppmerksomhet i den klinisk hverdagen.

\section{Kasusbeskrivelse}

\section{Generelle opplysninger om pasienten}

Pasienten var en ca. 40 år gammel kvinne som for flere år siden hadde s $\varnothing \mathrm{kt}$ psykiatrisk hjelp på grunn av depressive plager. Hun hadde aldri hatt hypomane/maniske symptomer og fikk diagnosen tilbakeven- dende depressiv lidelse. Antidepressiv behandling med SSRI og NSRI hadde vært fors $\varnothing \mathrm{kt}$ med effekt. Senere, etter ytterligere utredning, fikk pasienten diagnosen ADHD og startet med Ritalinbehandling. Hun opplevde god terapeutisk effekt av medikamentet på konsentrasjonsvanskene, men behandlingen ble seponert ca. 10 måneder senere etter at hun utviklet psykotiske symptomer med paranoide vrangforestillinger. På grunn av denne alvorlige bivirkningen anbefalte man i stedet behandling med Strattera. Pasienten fortsatte å ha depressive plager i perioder, og ble senere innlagt flere ganger ved psykiatrisk avdeling på grunn av akutt suicidalitet. Etter anbefalt daglig registrering av stemningsleie kunne man konkludere med at forandringene i psykisk status hadde sammenheng med menstruasjonssyklus, og at plagene oppstod i sen luteal fase (premenstruell uke). Pasienten kunne opplyse at hun hadde hatt liknende psykiske plager siden 16-17 års alder. Hun opplyste også at hennes mor og mormor også hadde hatt sterke premenstruelle plager.

Kliniske fenomener for behandling med Strattera ble satt $i$ gang

Pasienten opplyste at hun verken hadde psykiske plager eller suicidaltanker/impulser i follikulær fase av menstruasjonssyklusen. Hun beskrev den subjektive opplevelsen som om "man slår på en bryter" - både når psykiske plager oppstod ca. 1 uke før menstruasjonen og når de forsvant ved menstruasjonens start. Ved nærmere spørsmål vedrørende starten av plagene fant man at symptomene utviklet seg gradvis fra tidlig luteal fase og toppet seg i sen luteal fase - ca. 1-2 dager $f \varnothing \mathrm{r}$ bl $\varnothing$ dning. Som aller tidligste symptom merket pasienten $\varnothing \mathrm{kt}$ f $\varnothing \mathrm{lsom}$ het for lukt. Noe senere oppstod en opplevelse av utilpasshet og irritasjon, og pasienten følte seg mer utålmodig og kritisk til andre og ofte irritert på grunn av bagateller. Sensitivitet i interpersonlige forhold, spesielt til familiemedlemmer, $\varnothing$ kte. Negativ tankegang, som 
pasienten kalte "å ta en spade og grave frem alt fra fortiden", utviklet seg. Noe senere pleide pasienten å få tanker om at hun ikke var verdt noe og at hun hadde gjort mange feil tidligere i livet. Økende skyldfølelse fulgte disse tankene. Like etter pleide pasienten å få flyktige suicidale tanker. Alle beskrevne fenomener forsvant ved menstruasjonen. Ofte startet blødningen om natta, og symptomene ble da borte i løpet av natta, spesielt hvis hun hadde fått en kraftig blødning. Ifølge pasienten våknet hun da som "et annet menneske". Ved små blødninger kunne plagene være til stede i ca. 1-1,5 døgn etter menstruasjonsstart, men i mye mindre grad. Gjentakende suicidaltanker hadde pasienten etter eget utsagn kun hatt i luteal fase i mange år, og hun hadde aldri gjort suicidalfors $\varnothing \mathrm{k}$.

\section{Kliniske fenomener etter at behandling} med Strattera ble satt $i$ gang

Behandlingen med Strattera førte til $\varnothing \mathrm{kt}$ alvorlighetsgrad av depressive symptomer og suicidalatferd i premenstruell uke. Pasienten ble så alvorlig deprimert at hun var sengeliggende 2-3 dager før menstruasjonen. Hun hadde en opplevelse av at "alt var kullsvart", og at hun "ikke klarte å tenke rasjonelt”. Siste 2-3 dager f $\varnothing \mathrm{r}$ menstruasjonen fikk hun "trang til å d $\varnothing$ ”. Dette resulterte i flere suicidalfors $\varnothing \mathrm{k}$ med intoksikasjoner og påfølgende akuttinnleggelser ved psykiatrisk avdeling. Pasienten pleide å få menstruasjon på sykehuset like etter innleggelsen med rask bedring av psykisk tilstand. Denne $\varnothing \mathrm{kt}$ alvorsgrad av symptomene førte til at pasienten hadde nesten konstante tanker om at symptomene ville komme tilbake om noen få uker, noe som representerte en stor tilleggsbelastning.

\section{Samspill mellom depresjon, håpløshet, suicidaltanker/impulser, impulsivitet og affektregulering}

I intervju med pasienten ble det lagt særlig vekt på utviklingen av depressive symptomer, håpløshet, suicidaltanker/impulser, impulsivitet og emosjonell reaktivitet.

I sen lutealfase (fra 21. dag) beskrev pasienten $\varnothing$ kende intensitet av de depressive symptomene, $\varnothing$ kende håpløshet, $\varnothing$ kende intensitet i suicidaltanker - disse symptomene forsvant brått etter at blød-

Endringer i serumnivå av kvinnelige kjønnshormoner gjennom ulike faser av menstruasjonssyklus

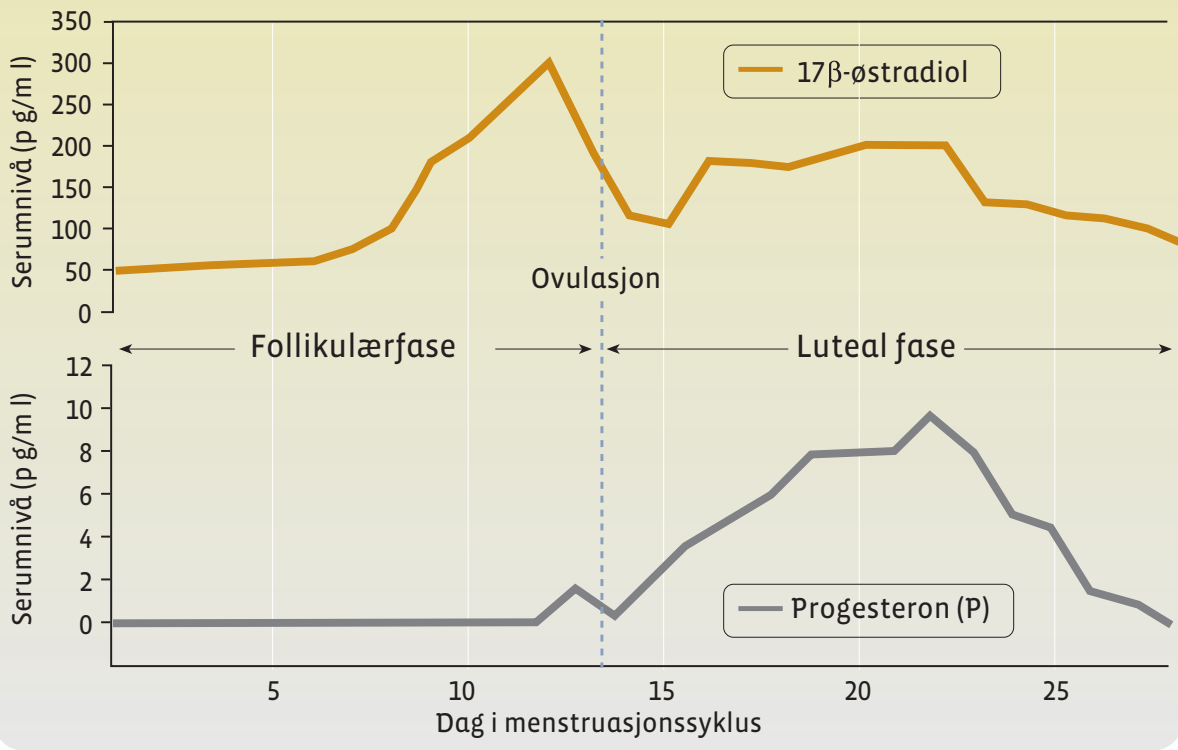

ning fant sted. Emosjonell reaktivitet steg vanligvis gradvis fra tidlig lutealfase, med fallende reaktivitet $2-3$ dager før menstruasjon. Impulsivitet steg gradvis fra tidlig lutealfase med betydelig reduksjon rett etter menstruasjonsstart.

\section{Aktuell behandling og utvikling $i$ pasientens tilstand}

Behandling med Strattera ble seponert etter ca. 1 års bruk, og pasienten startet med behandling med Zoloft. Tilstanden ble bedre, med betydelig reduksjon av premenstruelle plager og fravær av suicidal atferd. Pasienten opplyser at hun ikke har suicidale tanker i luteal fase nå.

\section{Diskusjon}

\section{Diagnostiske forhold}

Diagnosen PMDD ble først gitt etter at pasienten hadde utført daglig registrering av sine plager. Prospektiv daglig registrering av plagene kreves ifølge DSM-IV for å stille diagnosen. For å tilfredsstille DSM-IVs diagnostiske kriterier må en kvinne ha minst 5 av 11 definerte symptomer til stede i løpet av den symptomatiske perioden og minst ett av dem må være av affektiv karakter. Symptomer må oppstå og forsvinne i bestemte faser av menstruasjonssyklusen, fremkalle alvorlige forstyrrelser i funksjonsnivå relatert til arbeid, sosiale og mellommenneskelige forhold og ikke skyldes en annen psykisk eller fysisk lidelse.
Komorbiditet mellom PMDD og andre psykiske lidelser er godt kjent (Kim et al., 2004). Man bør skille mellom komorbiditet i livstidsperpektiv - hvis en kvinne med PMDD har hatt en annen psykisk lidelse tidligere i livet, "concurrent comorbidity" - en psykiatrisk eller somatisk lidelse som en kvinne har samtidig med PMDD uten at de påvirker hverandre, og den typen av komorbiditet som medfører at en somatisk eller psykisk lidelse forverrer seg før menstruasjonen (Yonkers et al., 2008).

\section{Patofysiologiske forhold}

Pasienten opplyste at både mor og mormor hadde hatt liknende premenstruelle plager. Det er påvist en sammenheng mellom varianter i $\varnothing$ strogen-reseptor alfagenet (Estogen Reseptor Alpha Gene) og PMDD (Huo et al., 2007). I det aktuelle kasus har suicidal atferd, depressive symptomer og håpløshet tydelig syklisk karakter og oppstår i premenstruell uke når progesteron- og østrogennivåene er lave. Likevel skiller ikke konsentrasjonen av østrogener og progesteron hos PMDD-pasienter seg fra friske personer (Rubinow \& Schmidt, 2006), og premenstruelle plager forsvinner ikke under behandling med progesteronreseptor antagonisten mifepristone (Birzniece et al., 2006), som man kunne vente dersom det var en enkel årsakssammenheng mellom progesteronkonsentrasjonen og premenstruelle plager. 
Progesteronmetabolitten allopregnanolon fungerer som agonist på GABA-Areseptorer. Allopregnanolon kan spille en rolle i patogenesen av PMDD via toleranseutvikling, direkte påvirkning av GABA-A-reseptorer eller gjennom en "withdrawal"- effekt. Brått avbrudd i eksponering av GABA-A-reseptorer for allopregnanolon fører til at GABA-A-reseptorer blir ufølsomme for agonister. Disse virkningene oppstår på grunn av oppregulering av $\alpha 4$ subenhet i reseptoren som igjen fører til GABA-A-nedregulering av selve reseptoren (Smith, 2002).

\section{Det kliniske bildet}

Ved rask senkning av allopregnanolonkonsentrasjon kan man klinisk observere symptomer som svekket impulskontroll, irritabilitet, depressive symptomer og angst (Backstrom et al., 2003). Både depresjon og impulsivitet er kjente risikofaktorer for suicidal atferd. Såkalt internaliserende psykiske lidelser (som depresjon og angstlidelser) er betydelig hyppigere hos kvinner, og disse lidelsene ser ut til å disponere for suicidaltanker og selvmordsfors $\varnothing \mathrm{k}$ (Beautrais, 2002). Pasientens klare beskrivelser av forandret kognisjon i premenstruell uke samsvarer med en studie der man påviste at pasienter med PMDD oppfattet samme livshendelser som mer ubehagelige i luteal fase enn de gjorde i follikulær fase (Schmidt et al.,1990).

Forstyrrelser i interpersonlig kommunikasjon, sosialt liv og arbeid hos kvinner med PMDD oppstår i samme grad som ved alvorlig depresjon (Freeman, 2003). Behandling med Strattera førte til forverring av plagene og flere suicidalfors $\varnothing \mathrm{k}$ hos pasienten i det aktuelle kasus. Forverring av suicidalitet er en kjent bivirkning av Strattera (Paxton \& Cranswick, 2008; 2005b; 2005a). Interessant nok forverret behandling med Strattera symptomer både på depresjon og intensitet av suicidal atferd, mens det sykliske mønsteret forble uforandret.

\section{Behandling}

Flere dobbelt-blind-plasebokontrollerte studier har vist positiv effekt av medisiner som $\varnothing$ ker serotoninkonsentrasjonen i hjernen for å behandle PMDD (oppsum- mert i en oversiktsartikkel av Rapkin, 2003). Pasientens tilstand har blitt betydelig bedre etter behandling med Zoloft (Sertralin).

\section{Konklusjon}

Ved repeterende suicidal atferd hos kvinner bør PMDD utelukkes. Behandling med SSRI kan ha positiv effekt.

Samtykke fra pasienten er innhentet og en del informasjon er endret for å bevare pasientens anonymitet.

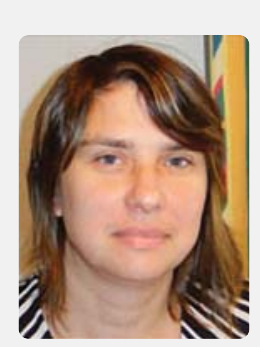

Alexandra Naletova er psykiater og arbeider ved DPS Gjøvik Poliklinikk Toten, samt som stipendiat ved Nasjonalt senter for selvmordsforskning og -forebygging. Hennes forskning fokuserer på sårbarhetsfaktorer for suicidalitet knyttet til menstruasjonssyklus.

\section{Refanser}

New warning about ADHD drug (2005a). FDA. Consum., 39, 3.

Warning on Strattera for attention-deficit hyperactivity disorder (2005b). FDA.Consum., 39, 4.

Baca-Garcia, E., Diaz-Sastre, C., Ceverino, A., Garcia R.E., Oquendo, M.A., Saiz-Ruiz, J. et al. (2004).

Premenstrual symptoms and luteal suicide attempts. Eur.Arch.Psychiatry Clin.Neurosci., 254, 326-329.

Baca-Garcia, E., Diaz-Sastre, C., Ceverino, A., PerezRodriguez, M.M., Navarro-Jimenez, R., Lopez-Castroman, J. et al. (2010). Suicide attempts among women during low estradiol/low progesterone states.

J.Psychiatr.Res., 44, 209-214.

Baca-Garcia, E., Diaz-Sastre, C., de, L.J., \& SaizRuiz, J. (2000). The relationship between menstrual cycle phases and suicide attempts. Psychosom.Med., 62, 50-60.

Backstrom, T., Andersson, A., Andree, L., Birzniece, V., Bixo, M., Bjorn, I. et al. (2003). Pathogenesis in menstrual cycle-linked CNS disorders. Ann.N.Y.Acad.Sci., 1007, 42-53.

Beautrais, A.L. (2002). Gender issues in youth suicidal behaviour. Emerg.Med.(Fremantle.), 14, 35-42.

Birzniece, V., Backstrom, T., Johansson, I.M.,

Lindblad, C., Lundgren, P., Lofgren, M. et al. (2006). Neuroactive steroid effects on cognitive functions with a focus on the serotonin and GABA systems. Brain Res.Rev., 51, 212-239.

Braverman, P.K. (2007). Premenstrual syndrome and premenstrual dysphoric disorder. J.Pediatr. Adolesc.Gynecol., 20, 3-12.

Cleckner-Smith, C.S., Doughty, A.S., \& Grossman, J.A. (1998). Premenstrual symptoms. Prevalence and severity in an adolescent sample.

J.Adolesc.Health, 22, 403-408.
Freeman, E.W. (2003). Premenstrual syndrome and premenstrual dysphoric disorder: definitions and diagnosis. Psychoneuroendocrinology, 28 Suppl 3, 25-37.

Halbreich, U. (2010). Women's reproductive related disorders (RRDs). J.Affect.Disord., 122, 10-13.

Halbreich, U., Backstrom, T., Eriksson, E., O'Brien, S., Calil, H., Ceskova, E. et al. (2007). Clinical diagnostic criteria for premenstrual syndrome and guidelines for their quantification for research studies. Gynecol.Endocrinol., 23, 123-130.

Halbreich, U., Borenstein, J., Pearlstein, T., \& Kahn, L.S. (2003). The prevalence, impairment, impact, and burden of premenstrual dysphoric disorder (PMS/PMDD). Psychoneuroendocrinology, 28 Suppl 3, $1-23$.

Huo, L., Straub, R.E., Roca, C., Schmidt, P.J., Shi, K., Vakkalanka, R. et al. (2007). Risk for premenstrual dysphoric disorder is associated with genetic variation in ESR1, the estrogen receptor alpha gene. Biol.Psychiatry, 62, 925-933.

Keye, W.R., Jr., Hammond, D.C., \& Strong, T. (1986). Medical and psychologic characteristics of women presenting with premenstrual symptoms. Obstet.Gynecol., 68, 634-637.

Kim, D.R., Gyulai, L., Freeman, E.W., Morrison, M.F., Baldassano, C., \& Dube, B. (2004). Premenstrual dysphoric disorder and psychiatric comorbidity. Arch. Womens Ment. Health, 7, 37-47.

Paxton, G.A. \& Cranswick, N.E. (2008). Acute suicidality after commencing atomoxetine. J.Paediatr.Child Health, 44, 596-598.

Rapkin, A. (2003). A review of treatment of premenstrual syndrome and premenstrual dysphoric disorder. Psychoneuroendocrinology, 28 Suppl 3, $39-53$.

Rubinow, D.R. \& Schmidt, P.J. (2006). Gonadal steroid regulation of mood: the lessons of premenstrual syndrome. Front Neuroendocrinol., 27, 210-216.

Saunders, K.E. \& Hawton, K. (2006). Suicida behaviour and the menstrual cycle. Psychol.Med., 36, 901-912.

Schmidt, P.J., Grover, G.N., Hoban, M.C., \& Rubinow, D.R. (1990). State-dependent alterations in the perception of life events in menstrual-related mood disorders. Am.J.Psychiatry, 147, 230-234.

Smith, S.S. (2002). Withdrawal properties of a neuroactive steroid: implications for $\operatorname{GABA}(\mathrm{A})$ receptor gene regulation in the brain and anxiety behavior. Steroids, 67, 519-528.

Wittchen, H.U., Becker, E., Lieb, R., \& Krause, P. (2002). Prevalence, incidence and stability of premenstrual dysphoric disorder in the community. Psychol.Med., 32, 119-132.

Yonkers, K.A., O'Brien, P.M., \& Eriksson, E. (2008). Premenstrual syndrome. Lancet, 371, 1200-1210. 